\title{
Influence of Demographic Variables on Organizational Commitment of School Teachers: Evidence from the Kathmandu Valley, Nepal
}

\author{
Sarita Agrawal $^{*} \oplus$, Bandana Kumari Jain ${ }^{2} \odot$
}

1 Lecturer, Quest International College, Pokhara University, Lalitpur, Nepal

2 Lecturer, Faculty of Management, Post-Graduate Campus, Tribhuvan University, Biratnagar, Nepal

* Corresponding Author (sarita@ quest.edu.np)

Received: 13 August, 2020 Revised: 29 October, 2020 Accepted: 08 November, 2020 Published: 15 December, 2020

How to cite this paper:

Agrawal, S., \& Jain, B.K. (2020). Influence of demographic variables on organizational commitment of school teachers: Evidence from the Kathmandu Valley, Nepal. Quest Journal of Management and Social Sciences, 2(2), 262-274.

Copyright (C) 2020 by authors and Quest Journal of Management and Social Sciences.

This work is licensed under a Creative Commons Attribution-Non Commercial-No Derivatives 4.0 International License.

https://creativecommons.org/

licenses/by-nc-nd/4.0/

\begin{abstract}
Background: Teachers are actors and thus play various roles and responsibilities in the classroom, school and entire community. Their commitment contributes to increasing the skills, knowledge, creativity, intelligence, devotion, and attitudes of the school community. The demographic heterogeneity of teachers affects not only performance but also the commitment level of the school community.
\end{abstract}

Objectives: The study aims to find the influence of demographic variables on the organizational commitment of school teachers in Kathmandu and Lalitpur districts.

Methods: This study is quantitative and based on primary data. The study has employed a conclusive research design. The population of the study was secondary level teachers in Kathmandu and Lalitpur districts, and a number of them were selected using the principles of purposive sampling. The size of the sample was 232.

Results: The study reveals that affective, continuance, normative as well as overall commitment of teachers in school do not differs in terms of gender and education level. However, affective commitment increases as an increase in service years whereas continuance commitment increases at the beginning years of service for five years. However,between five to ten years, it lessens. Again after ten years, it increases if the teacher is involved in the same job for one decade.

Conclusions: The commitment of teachers is not affected by their gender and education level. However, the years in service spent by teachers influence their affective and continuance commitment but not the normative commitment.

Implications: The findings of this study can be useful for school administrators and policymakers to find the influence of demographic factors on the commitment of school teachers.

Keywords: School, teachers, affective commitment, continuance commitment, normative commitment, teachers' commitment.

Paper Type: Research Paper

JEL Classification: D23, D73, L22 


\section{Introduction}

The commitment of school teachers is regarded as the psychological connection of teacher's individual goals with the all-inclusive goal of the school, their concentration in joining their identity with the school, and lastly to have the intention to work the school for a long time (Wagner \& Hollenbeck, 2010; Cohen, 2007). Hence, increasing the commitments of teachers should be the major goal of the school management, it leads to creating productive and prolific teaching staffs (Padmavathy \& Premavathy, 2018). The teachers, who have a low level of commitment, do not only dissuade the successful performance of their pedagogical duties but also exceedingly hamper the accomplishments of the goals of school and community in total (Cohen, 2007). The most acceptable and common view regarding the commitment of teachers signifies that highly committed teachers want to put additional efforts and accept extra roles and responsibilities to realize the school objectives. Consequently, teachers' commitment also aids to lessen staff turnover (Tett \& Meyer, 1993; Meyer, Stanley Herscovitch \& Topolnytsky, 2002). All the educational institutions intend to be efficient, effective, and successful in their work and sustain in society by contributing to their existence and the overall interest of society at large. Proprietors of school, teachers, students, parents, and society are the five pillars on which that a school stands. There is a prerequisite of school to be responsible and accountable towards teachers for the fulfillment of individual interests of founders as well as attainment of the group goal of the school. Teachers are imperative agents to realize the collective goals of educational institutions (Clarence \& George, 2018; Tsui \& Cheng, 1999). Nonetheless, the excellence and dedication of teachers lead the organization's success (Pohlman \& Gardiner, 2000).

The satisfaction of schools' stakeholders and innovation in education largely depends on teachers, who are prime and evident for executing school activities (Sezgin, 2009). Findings of many studies suggest that personal characteristics or demographic variables such as gender, age, years of experience, education level of teachers relate to their organization's commitment (Tsui \& Cheng, 1999; Klag \& Bradley, 2004; Angle \&perry, 1981; Steers, 1977). Unfortunately, the studies done previously did not have similar views concerning the relationships of demographic variables and organizational commitment. They were also very difficult to summarize (Salancik, 1977; Meyer \&Allen, 1991; Elizur \& Koslowsky, 2000). A significant number of studies were involved in investigating the impact of various factors on organizational commitment and the majority of them considered the demographic factors (Konya, Matic \& Pavlovic, 2016). Pala, Eker, and Eker (2008); Ritzer and Trice (1969); Aven, Parkey, and McEvoy (1993) explored that gender, level of education, years in service, marital status, age, occupation, and title of the position in the organization were related to organizational commitment. However, paradoxically,some studies have found that demographic factors were not significant predictors of organizational commitment (Salami, 2008). As such, there are very divergent views regarding this issue, subsequently, further research is necessary for this subject.

This study aims to find the influence of demographic variables of teachers on their commitment in Kathmandu and Lalitpur districts. This study can contribute to enhancing the value of the school through improving the knowledge systems and insights of the school investors, social institutions, principle, and coordinators of the school, concerning the impact of demographic variables on the commitment of teachers in school. At the same time, the study can also be fruitful to develop the plans and policies regarding the tools needed by institutions to develop the commitment of teachers.

This study is divided into six sections. The first section is concerned with the background of the study, in which an overall overview of the study is mentioned. Similarly, the second section is the literature review where the studies done in the past, related to the concerned topics of the study, have been reviewed. The third section is a research methodology where research design and sampling are mentioned. The fourth section is the result under which result of data analysis and its interpretation is declared. The fifth section is discussion where the result of present study is discussed with the studies 
done in past having the similar issue. The sixth and final section is conclusion where the conclusion, implication and recommendation for further study are revealed.

\section{Review of Literature}

\section{An Overview of Organizational Commitment}

The particular state, in which employees ascertain themselves with a specific organization and its goals, and wishes to maintain membership in the organization and has been recognized as the key measure of intellectual health, is known as organizational commitment (Robbins \& Langton, 2003; Warr, 1987). Porter and his associates define organizational commitment as the relative power of individuals to connect their identity with a specific organization (Mowday, Porter, \& Steers, 2013; Porter, Crampon, \& Smith 1976; Porter, Steers, Mowday, \& Boulian, 1974). Prominent researchers Meyer and Allen proposed three types of approaches for understanding organizational commitment. This viewpoint on commitment includes three general themes: "affective connection to the organization, perceived costs coupled with leaving the organization and compulsion to remain with the organization". These three themes are generally referred to as: 1) affective commitment, 2) continuance commitment, and 3) normative commitment (Meyer \& Allen, 1991).

Kantar (1968) focuses on the idea that affective commitment is solidity commitment, which represents attachment of an individual's fund of affectivity and emotion to the group. Continuance commitment refers to an acute awareness of the perceived costs associated with leaving the organization. When the costs associated with leaving the organization are perceived to be greater than the potential benefits, continued employment occurs solely because the individual needs to remain with the organization (Meyer \& Allen, 1987, 1988; Rhodes \& Steers, 1981). Normative commitment reflects a feeling of personal obligation to remain with the organization (Wiener, 1982). Strong normative commitment creates continued employment because employees feel that they ought to remain with the organization (Meyer \& Allen, 1991). The internalized pressure generally enhances due to the learning of children to remain loyal to the employers or anyone from their parents. At a macro level, cultures may perform a similar thing to their members by emphasizing the importance of the collective rather than the individual (Meyer \& Allen, 1991).

\section{A General View of Teachers' Commitment}

Teaching is defined as an interpersonal influencing job, producing a significant set of externalities and benefits not only to one particular individual but to the entire society and nation. They are actors and play various roles and responsibilities in the classroom, in the school, and the community (Moore \& Moore, 2014). Similarly, Tarter, Hoy, and Kottkamp (1990) conjectured that school health and organizational commitment are associated. Teachers' organizational commitment and teachers' effectiveness strengthen each other, and teachers' worth, in turn, stimulates student accomplishment (Sezgin, 2009). Teachers are known to be committed when their individual goals and organization goals harmonize with each other and their work shows citizenship behavior to achieve the institutional goal (Cohen 2007). As per the study of Mathew (2003), currently, educational institutions are at a crossroads. They expect high commitments from teachers but teachers are headed in the opposite direction. As per the arguments of the head of educational institutions, there is the problem of organizational commitment in teachers. They frequently quit their jobs within a short duration of their service, remain absent for a long period of time in which they remain in burnout, and form groups for their collective voice due to their demographic heterogeneity.

\section{Influence of Demographic Variables on Teachers' Commitment}

Demographics are the statistics of quantifications of a given population and are concerned with the quantification of sub-sets like race, gender, occupation, population density, size, and location (Blythe 
\& Martin, 2019; Kotler \& Armstrong, 2001). There is evidence of many studies, which have found relationships between demographic variables like gender, age, years of experience, education level with teachers' commitment (Karrasch, 2003; Tsui \& Cheng, 1999; Hannah \& Morrisey, 1986; Klag \& Bradley, 2004). However, the relationships are neither well-built nor fixed. More curiously, even when relationships were observed, they could not be interpretted unambiguously (Salancik, 1977; Meyer \& Allen, 1991; Elizur \& Koslowsky, 2000). Nonetheless, many studies confirmed that the predictors of commitment to the values of the organization are the personal characteristics and working experiences of employees. The deep-rooted benefits are reduced fluctuations and absenteeism, a higher level of attendance to work and work performance, organizational citizenship behavior (OCB) and positive impact on employee health (Meyer \& Allen, 1997; Meyer et al., 2002).

Gender has a high impact on employees' organizational commitment, due to the socio-psychological categories of masculinity and femininity. Some studies exposed that women are more committed to their organizations (Klag \& Bradley, 2004) whereas other studies dogged men as more committed than women (Sigh \& Sifflette, 1996). However, some studies revealed that women usually have less experience at work, they exhibit less commitment to the organization (Loscocco, 1990). On the other hand, other studies revealed that gender is unrelated to organizational commitment (Khalili \& Asmawi, 2012). Organizational commitment is affected by another factor: education. People with lower education levels and qualifications are seen as more committed to their organization and they rarely like to switch to another job or another organization (Steers, 1977; Angle \& Perry, 1981; Mathieu \& Zajac, 1990; Eskildsen, Kristensen \& Westlund, 2004). In contrast, Pala and colleagues found a direct and positive relationship between education levels and an employees' commitment to their organization (Pala, Eker \& Eker, 2008).

The study, which was conducted in Pakistan, revealed that the length of tenure has a positive relationship whereas educational level has a negative relationship with organizational commitment. However, there is no relationship between the ages of the employees and organizational commitment (Iqbal, 2010). In another study, Sabir, Maqsood, Tariq and Devkota (2019) found that happiness at work has significant impact on organizational citizenship behaviors of teachers. However, a study done in Nigeria explored that many demographic variables like age, education, job tenure, job position have a significant impact on organizational commitment (Konya, Matic \& Pavlovic, 2016). Mathieu and Zajac (1990) found a positive link between organizational tenure and affective commitment. The robust positive correlations between tenure and commitment are consistent with previous studies (Rousseau \& parks 1993; Meyer, Allen \& Gellatly 1990; Salami, 2008). Some studies also specify that older workers are more committed while newly hired workers are not (Khurshid, Fauzia \& Parveen, 2015). Igbeneghu and Popoola (2010) reported that personal characteristics like marital status and length of service have a significant positive correlation with organizational commitment.The study that was done on college teachers also found that those who work for long years have a higher organizational commitment (Khurshid et.al. 2015).

In the context of Nepal, a very nominal study was done concerning the commitment of school teachers. Though several studies were completed concerning the job satisfaction of teachers (Shrestha, 2019a; Shrestha, 2019b), the study concerning teachers' commitment is lacking. This study can add one brick for further study of this concern.

\section{Research Method}

\section{Study Area}

The study has employed a conclusive research design under which descriptive and analytical research design was employed for the analysis of data. The population of the study consisted of all teachers of private secondary schools in Kathmandu and Lalitpur districts. The total number of secondary teachers in Kathmandu is 3578, whereas in Lalitpur is 1566 (Ministry of Education, flash report, 2018). The 
sample selected participants out of the population, using a purposive sampling. It was because under purposive sampling, subjects are selected based on study purpose with the expectation that each participant will provide unique and rich information of value to the study (Etikan, Musa \& Alkassim, 2016). As such, under this study, the researcher had collected the response only from those teachers who had properly understood the questionnaire and showed interest to provide response. The number of respondents used as a sample was 232 . The researcher had visited a total of 50 schools, where $20 \%$ of them were from Lalitpur and $80 \%$ from Kathmandu, due to a 1:5 ratio of the number of schools in Kathmandu and Lalitpur.

\section{Instrumental Development and Data Collection}

The study had included primary sources of data. The primary data was collected from the distribution of a structured questionnaire to the respondents. The questionnaire was of three types of commitment (Affective, Continuance, and Normative) and were taken from a previously developed scale by Meyer \& Allen (1991). To collect the information concerning teachers' commitment, six-item scales from negative to positive were developed from 1 to $6 .(1=$ strongly disagreed; $2=$ Disagreed; $3=$ Somehow disagreed, 4= Somehow agreed; $5=$ Agreed; $6=$ Strongly Agreed). The respondents were asked to tick anyone of them. Those respondents who ticked more than one were rejected and were not included in the study, to maintain the reliability and validity of the study.

The researcher had visited the participants their ownselves to collect the data. First, the number of schools to be visited were enlisted based on the objective of study. The researcher went to school and visited either the principal or academician in charge, first. Taking help from them, the teachers at the secondary level were visited. The questionnaires were distributed to teachers after providing a brief description of the questions. Altogether, one month was consumed for the collection of responses from respondents. Once the data were collected, the responses to the questionnaire survey were categorized, tabulated, processed, and analyzed with the help of SPSS (Version 20).

\section{Data Analysis}

Descriptive as well as inferential statistical tools were implied to achieve the intent of the study. For the descriptive analysis frequency, percentage of demographic information of data (gender, qualification, and service years) were calculated and interpreted. Correspondingly, for inferential analysis, independent sample t-test and one-way ANOVA test (to measure the mean difference of variables) were employed. The P-value was equaled to the significance level, based on which the null hypothesis was either rejected or accepted. For the internal consistency of variables, the reliability test Cronbach Alpha $(\alpha)$ had been calculated for teachers' commitment. The Cronbach Alpha $(\alpha)$, for teachers' commitment, was 0.743. The individual Cronbach Alpha $(\alpha)$ for affective commitment was 0.694, continuance commitment was 0.650 and normative commitment was 0.6. A scale greater than 0.70 is accepted and followed for the internal consistency of variables (Nunnaly \& Bernstein, 1994). However, Schmitt (1996) had suggested that there is no general level (such as 0.70) where alpha becomes acceptable, but rather that instruments with quite a low value of alpha can still prove useful in some circumstances. To confirm the content validity of the instruments, previously developed and tested sets of the questionnaire were used. Moreover, to ensure context validity, the study had modified the questionnaire following place, level of education, and other factors of the required respondents. After the modification of relevant questions for the study, the questionnaire made available for an overview by some experts for their suggestion and comments. Then the needed corrections made accordingly, which refers to the subjective agreement among professionals that a scale was logically appeared to accurately measure what was intended to measure (Zimkund,2003). The research questionnaire was also pre tested in the pilot phase, by selecting twenty-five teachers from the population. Some amendment was done in the questionnaires based on feedback and suggestion of respondents. The validity of the sample was based on the accuracy and precision of the questionnaire. 


\section{Data Analysis and Results}

\section{Demographic variables}

This study finds that the majority of the respondents are male; they cover $65.5 \%$ of the total number of respondents and the female are less than 50\% (see table 1). The majority of respondents, i.e. 147 (63.4\%), have a Master'sdegree or a Master's degree and above qualification. It denotes that most of the secondary level school teachers' have at least a Master's level of education. Similarly, $44.4 \%$ of respondents have less than or equal to five years of service, whereas $28.9 \%$ have greater than five or less than or equal to ten years of service providing time. Equally, one-fourth of the respondents had more than ten years of service provided. It signifies that the majority of the respondents' working as a secondary level school teachers have less than or equal to five years of service.

Table 1. Demographic profiles of teachers

\begin{tabular}{lccc}
\hline \multicolumn{1}{c}{ Variables } & Categories & Number & Percent (\%) \\
\hline Gender & Male & 152 & 65.5 \\
& Female & 80 & 34.5 \\
& Total & $\mathbf{2 3 2}$ & $\mathbf{1 0 0}$ \\
Education & Bachelors & 85 & 36.6 \\
& Masters and above & 147 & 63.4 \\
& Total & $\mathbf{2 3 2}$ & $\mathbf{1 0 0}$ \\
Service & $\leq 5$ & 103 & 44.4 \\
& $>5 \leq 10$ & 67 & 28.9 \\
& Above 10 & 62 & 26.7 \\
& Total & $\mathbf{2 3 2}$ & $\mathbf{1 0 0}$ \\
\hline
\end{tabular}

\section{Factors Influencing variables of Teachers' Commitment}

This section represents factors that influence the variables of teachers' commitment. Under this independent sample, t-test and one-way ANOVA are used to find the influence of demographic variables on various types of teachers' commitment.

Table 2: Demographic factors influencing on variables of teachers' commitment

\begin{tabular}{llll}
\hline \multicolumn{1}{c}{ Variables } & Affective Commitment & Continuance Commitment & Normative Commitment \\
\hline Gender & $\mathrm{t}=-0.449$ & $\mathrm{t}=0.391$ & $\mathrm{t}=-0.655$ \\
& $(0.654)$ & $(0.696)$ & $(0.513)$ \\
Education & $\mathrm{t}=0.931$ & $\mathrm{t}=0.941$ & $\mathrm{t}=0.452$ \\
& $(0.352)$ & $(0.347)$ & $(0.652)$ \\
Service Years & $\mathrm{F}=3.717^{*}$ & $\mathrm{~F}=5.113 *$ & $\mathrm{~F}=1.354$ \\
& $(0.025)$ & $(0.006)$ & $(0.259)$ \\
\hline
\end{tabular}

* means the statistics are significant at a 5\% level of significance and the value in brackets are $\mathrm{P}$ value. In table-2, the independent sample t-test result shows that there is no significant difference for gender $(\mathrm{P}=0.654>0.05)$ and education $(\mathrm{p}=0.352>0.05)$ in affective commitment at a $5 \%$ level of significance. The result of ANOVA analysis shows that there is a significant mean difference in affective commitment relating to service years $(p=0.025<0.05)$. Similarly, for continuance commitment, the independent sample t-test result displays that there is no difference relating to gender $(\mathrm{p}=0.696>0.05)$ and education $(p=0.347>0.05)$ in the average value of continuance commitment. The test of ANOVA analysis shows 
concerning years of service, there is a difference in the average value of continuance commitment $(p=0.006<0.05)$. Correspondingly, concerning normative commitment the independent sample t-test result shows there is no mean difference in normative commitment relating to gender $(\mathrm{p}=0.513>0.05)$ and education $(\mathrm{p}=0.652>0.05)$. The test of ANOVA analysis denotes that there is again no difference in normative commitment to service years because the result is insignificant.

In other findings, there are only service years that influence overall teachers' commitment (Table 3). As shown in table 3 , the result is significant at a $5 \%$ level of significance $(p=0.029)$. Whereas other variables like gender and education have no influence on overall teachers' commitment.

Table 3: Demographic variables and overall teachers' commitment

\begin{tabular}{ll}
\hline \multicolumn{1}{c}{ Variables } & \multicolumn{1}{c}{ Statistical tool } \\
\hline Gender and Teachers' Commitment & $\mathrm{t}=-0.323(\mathrm{p}=0.747)$ \\
Education and Teachers' Commitment & $\mathrm{t}=1.018(\mathrm{p}=0.309)$ \\
Service years and Teachers' Commitment & $\mathrm{F}=3.554(\mathrm{p}=0.029 * *)$ \\
\hline
\end{tabular}

** means the statistics are significant at a $5 \%$ level of significance.

\section{Post-hoc test}

Post-hoc test least significant difference (LSD) shows in table 4 that respondents who have greater than ten years of service have a higher score in affective commitment than those who have less than or equal to five years of service. Similarly, it indicates that the respondents who have less than or equal to five years of service have a high score in continuedcommitment than the respondents who have greater than five but less than or equal to ten years of service. Similarly, the respondents who have above ten years of service years have a high score in continuance commitment than the respondents who have greater than five but less than or equal to ten years of service.

\section{Table 4: Post-hoc test-LSD for affective and continuance commitment to service years}

\begin{tabular}{|c|c|c|c|}
\hline I & $\mathrm{J}$ & Mean difference (I-J) & Significance \\
\hline$<5$ & Above 10 & $-.33855^{*}$ & .007 \\
\hline
\end{tabular}

Post-hoc test-LSD for continuance commitment to service years

I J Mean difference (I-J) Significance

$\begin{array}{llll}\leq 5 & >5 \leq 10 & .33401 * & .006\end{array}$

\begin{tabular}{lll} 
Above10 & $>5 \leq 10$ & $.38485^{*}$ \\
\hline
\end{tabular}

\section{Discussion}

The study reveals that gender, i.e. male and female, has no different scores relating to affective commitment, continuance commitment, and normative commitment. The study is in the same line as the study of Sepahvand, Atashzadeh-Shoorideh, Parvizy, and Tafreshi (2017), Al-Hawajreh (2012) and Meyer et al. (2002). It might be because today's life is full of economic stress as well as prioritization of equal gender mix , equal responsibilities and obligations in the workplace. So, the question of single patronage of men and women is no more an isolated issue (Sepahv and et.al. 2017). The study is not consistent with the result of the study in Turkey in school administrators and teachers, where it was found that male employees had more affective commitment than females (Sezgin, 2009). Likewise, Padmavathy and Premavathy (2018) also found that a male employee is more committed to their work because females have to give major attention to their home rather than a job. And thus they do not 
get time to develop informal relationships with other staffs of the organization and outside people, which normally decreases their commitment as comparison to male employees. Furthermore, some gender studies have also gathered the argument that men and women have different psychological traits, which lead to a varied level of commitment. For example, women are said to have a higher social interest than men,which leads to a higher commitment in women (Giele, 1988). Another reason could be the domestic responsibilities that prevent female employees from searching for jobs beyond the geographic area in which they reside. They want to remain close with their family, which again minimizes their new choices of job in the market and increases their commitment to the organization where they work (Kimosop, 2018).

The result has shown that the level of education whether i.e. less or more does not affect the affective, continuance, and normative commitment. This study is in the same delineation of study as that of Sepahvand et al., (2017), where it was found that education level has no significant difference in any type of commitment. It might be possible for this study because the majority of respondents had been awarded a Master's degree and more, and very few had less than that level of education, which normally does not show the varied result. It must also be denoted that when the majority of the respondents have the same level of qualification in the same profession, it does not affect their affective, continuance, and normative commitment. The findings are not consistent with the study of Loscocco (1990) and Meyer and Allen, (1997). Conferring to the findings of many researchers, those who have an advanced level of education experience ease, security, opportunities, and advantages. More precisely, it can be said that teachers who have greater qualifications acquire a good position in serving the organization which usually accelerates higher organization commitment (Loscocco, 1990; Meyer \& Allen, 1997). But other researchers found that undergraduate teachers possess high organizational commitment in comparison to postgraduate teachers. It is because they have less expectations and they remain happy with the rewards and recognition they get for their efforts (Padmavathy\&Premavathy, 2018).

The result of the study has revealed that there is a significant difference in affective commitment. The respondents who have many service years, i.e. greater than ten, have high affective commitment than those who have less than or equal to five years of service. It specifies that higher the service years are, higher the affective commitment. The finding is parallel with the finding of Joiner and Bakalis (2006), Parveen (2015), Tough and Popoola (2009). The reason behind this could be their age factor which affects their energy and experiment. At the beginning of their career, they are not convinced that teaching is the only and the most imperative option for them. There is also a high likelihood to switch to another job and organization that can pay them more salary, incentives, benefits, and facilities. Additionally, the reason could be their less familiarity with the climate and culture of the organization which further becomes the cause of less commitment (Clarence \& George, 2018).

The result concerning continuance commitment confirms that the respondents who have less than or equal to five years of service experience have a high score in continuance commitment than the respondents who have greater than five but less than or equal to ten years of service. It is obvious because they need to prove their excellence and want to make their identity in the organization but those who have high service years feel monotonous in the job. They are also less committed due to unmatched salary as well as a rigid mindset into their job (Saremi \& Bahdori, 2015). Similarly, the respondents who have above ten years of service have a high score in continuance commitment than those who have greater than five but less than or equal to ten years of service. The reason behind this could be that they get higher job responsibilities and a better position in the organization. Besides, another reason might be they get fewer opportunities in the market due to a single type of experience in the same organization for a long time (Mowday et al., 2013).

Concerning normative commitment, the study has found that the service years are less or more does not affect the normative commitment of teachers. The result does not look strange because of the highly cited researchers, Meyer \& Allen (1991). They explored that normative commitment is developed, 
according to their respective culture and family in which people have grown up. The other factors concerning the organization like service years, gender, qualification, age, and other else have no effect in the normative commitment of people in the organization. However, the study is not consistent with the study of Karakus \& Aslan (2009) where it was found that teachers have a high amount of normative commitment during one to five years of tenure in service.

In our study, no significant difference is found between gender and overall teachers' commitment. This designates that the average score of overall teachers' commitment does not differ by gender. The result concurs with the study of Feather and Rauter (2004); Shaw and Reyes (1992) and Turner and Chelladurai (2005). However, the study of Klag and Bradley (2004); Sezgin (2009) concluded that female seems more committed into their jobs in comparison to male. Similarly, considering the education levels and the overall teachers' commitment, the result is insignificant. The study doess not agree with other studies that have found a negative relationship between teachers' organization commitment and level of education (Steers (1977); Al-Kahtani (2012) and Iqbal, Kokash \& Al-Oun (2011)) but then positive relationsip was found by the study of Salami (2008).

In this study, service years and teachers' commitment has been found to be a significant relationship which directs the service years of teachers. The study agrees with the study of Sezgin (2009), where the result has found that only the years of service affect the teachers' commitment but not the age. The study also counters the study of Rousseau \& Parks (1993), Meyer, Allen, and Gellatly (1990), and Salami (2008). It looks genuine because the more the employees live in an organization, the more work experience is gained. At the same time, high attachment and belongingness to the organization contributes to the enhancement of their commitment levels (Joiner and Bakalis, 2006). Nevertheless, the study that was done by Konya et.al. (2016) also established that gender is one variable that does not affect commitment but service years, education, age affects teachers' commitment.

\section{Conclusion}

The study intended to examine the influence of demographic variables on the organizational commitment of school teachers. For that, the study employed an independent sample t-test and oneway ANOVA to find the influence of gender, education, and service years in the affective, continuance, and normative commitment, as well as, the overall commitment of school teachers in Kathmandu and Lalitpur districts. The study concludes that there is no difference in affective, continuance, and normative commitment concerning gender. The average score of both males and females was about the same, which indicates that both male and female teachers have no varied views concerning the level of commitment in school. Furthermore, the study concludes that the level of education, whether it is more or less, does not affect any type of commitment, whether they are affective, continuance, or normative commitment. It indicates that there should be other variables that can affect the teachers' commitment but not their level of education. It might be obvious because the teachers' profession is an intellectual job and all teachers establish their careers in schools only after having a high level of education. Therefore, some degree of variability in education level could not affect their commitment to the school.

Similarly, the study also concluded that those who have many service years, more than ten years, have a high level of affective commitment than those who have just started their job of teaching and have less than five years of service experience. But regarding continuance commitment, the study extracts dissimilar results and it establishes that those who have less than five years of service have high continuance commitment than those who have more than five but less than ten years of service in school. It indicates that the continuance commitment decreases in the service year time of five to ten years. Even though it is indicated that after ten years of service, it increases. It also seems obvious because there is less chance of being switching into another profession after having the same job for one decade. Another reason could be that it is a good position and like the responsibilities that they have after having the same job for a long time. Correspondingly, concerning overall teachers' commitment, 
the study confirms that gender and education do not but service years do affect the commitment of teachers in school.

The study can be beneficial for the school administrators and government to find the variables which affect the commitment of teachers. The study had included only three variables like gender, education, and service years of teachers to find their influence on the commitment of teachers. However, there could be the involvement of other variables like age, marital status, income level, family type (nuclear or joint), which might affect the commitment of school teachers. The study found the result through a structured questionnaire filled by respondents, but the other instruments like observation and interview for the focus group can be done for further analysis of the same type of study in the future. The study had not included the school in Bhaktapur of Kathmandu valley because of less accessibility to the schools for the researcher in that area. Further studies can include such study areas and other variables to find teachers' commitment in school for more authenticity of this type of study.

\section{Conflict of Interest}

There exists no conflict of interest between authors.

\section{References}

Al-Hawajreh, K. M. (2012). Exploring the relationship between occupational stress and organizational commitment among nurses in selected Jordanian hospitals. Dirasat: Administrative Sciences, 161(719), 1-34. doi: $10.12816 / 0000638$.

Al-Kahtani, S. N. (2012). An exploratory study of organizational commitment, demographic variables and job and work-related variables among employees in Kingdom of Saudi Arabia. Online International Interdisciplinary Research Journal, 3, 1-13.

Angle, H. L. and Perry, J. L. (1981). An empirical assessment of organizational commitment and organizational effectiveness. Administrative Science Quarterly, 1-14.

Aven, F. F., Parker, B., \& McEvoy, G. M. (1993). Gender and attitudinal commitment to organizations: A metaanalysis. Journal of Business Research, 26, 63-73.

Blythe, J., \& Martin, J. (2019). Essentials of marketing. Pearson UK.

Clarence, M \& George, T.S. (2018). Role of demographic variables in organizational commitment of catholic college teachers. Asia pacific journal of research, 1, 58-65.

Cohen, A. (2007). Commitment before and after: An evaluation and reconceptualization of organizational commitment. Human resource management review, 17(3), 336-354.

Elizur, D., \& Koslowsky, M. (2000). Values and organizational commitment. Internationalempirical investigation. Journal of Business Ethics, 15(6), 655-660.

Eskildsen, J. K., Kristensen, K. and Westlund, A. H., (2004). Work motivation and Job satisfaction in the Nordic countries. Employee Relations, 26 (2), 122 - 136.

Etikan, I; Musa, S.A.; Alkassim, R.S. (2016). Comparison of convenience sampling and purposive sampling. American Journal of Theoretical and Applied Statistics, 5 (1), 1-4. doi. 10.11648/j.ajtar.20160501.11.

Feather, N. T., \& Rauter, K. A. (2004). Organizational citizenship behaviours in relation to job status, job insecurity, organizational commitment and identification, job satisfaction and work values. Journal of occupational and organizational psychology, 77(1), 81-94.

Giele, J.G. (1988). Gender and Sex Role. Newbury Park, CA: Sage.

Hannah, T.E. and Morrisey, C. (1986). Correlates of psychological hardiness in Canadian adolescents. The Journal of Social Psychology, 1271(4), 339-44.

Igbeneghu, B. I., \& Popoola, S. O. (2010). Influence of age, marital status, length of service and job satisfaction on organizational commitment of medical records personnel in University teaching hospitals in Nigeria. Library Progress (International), 30(2), 237-268. 
Iqbal, A. (2010). An empirical assessment of demographic factors, organizational ranks and organizational commitment. International Journal of Business and Management, 5(3), 16.

Iqbal, A., Kokash, H. A., \& Al-Oun, S. (2011). The impact assessment of demographic factors on faculty commitment in the Kingdom of Saudi Arabian universities. Journal of College Teaching \& Learning (TLC), 8(2).

Joiner, T. A., \& Bakalis, S. (2006). The antecedents of organizational commitment: the case of Australian casual academics. International Journal of Educational Management, 20(6), 439-452. https://doi. org/10.1108/09513540610683694

Kantar, R. M. (1968). Commitment and social organization: A study of commitment mechanisms in utopian communities. American sociological review, 499-517.

Karakuş, M., \& Aslan, B. (2009). Teachers' commitment focuses: a three-dimensioned view. Journal of Management Development. https:// doi.org/10.1108/02621710910955967

Karrasch, A.I. (2003). Antecedents and consequences of organizational commitment. Military Psychology.15 (3), 225-36.

Khalili, A., \& Asmawi, A. (2012). Appraising the impact of gender differences on organizational commitment: Empirical evidence from a private SME in Iran. International Journal of Business and Management,7(5), 100-111. https://doi.org/10.5539/ijbm.v7n5p100

Khurshid, F., Parveen, N. (2015). Organizational commitment in relation to biographic variations among college teachers. Journal of Research in Social Sciences-JRSS, 3 (1), 96-106.

Kimosop, M. K. (2018). Empirical assessment of demographic factors influencing organizational commitment in secondary schools in Kenya. Paper presented in first international conference, US.

Klag, S. and Bradley, G. (2004). The role of hardiness in stress and illness: an exploration of the effect of negative affectivity and gender. British Journal of Health Psychology, 9(1), 37-61.

Konya, V., Matić, D., \&Pavlović, J. (2016). The influence of demographics, job characteristics and characteristics of organizations on employee commitment. ActaPolytechnicaHungarica, 13(3), 119-138.

Kotler, P., \& Armstrong, G. (2001). Marketing: edición para Latinoamérica. Pearson Educación.

Loscocco, K. A. (1990). Reactions to blue-collar work: a comparison of women and men. International Sociological Journal, 17 (2), 152-177.

Mathew, T. C. (2003). A study of organizational commitment of degree college teachers in relation to work values, self-actualisation and leader behaviour of principals. Indian Educational Abstracts, 4(1), 86-87.

Mathieu,J.E and Zajac,D.M.(1990). A review and meta-analysis of the antecedents, correlates, and consequences of organizational commitment. Psychological Bulletin,108,171-194.

Meyer, J. P., \& Allen, N. J. (1987). A longitudinal analysis of the early development and consequences of organizational commitment. Canadian Journal of Behavioural Science, 19(2), 199-215.

Meyer, J. P., \& Allen, N. J. (1988). Links between work experiences and organizational commitment during the first year of employment: A longitudinal analysis. Journal of Occupational Psychology, 61(3), 195-209.

Meyer, J. P., \& Allen, N. J. (1991). A three-component conceptualization of organizational commitment. Human Resource Management Review, 1(1), 61-89.

Meyer, J. P., \& Allen, N. J. (1997). Commitment in the workplace: Theory, research, and application. Sage.

Meyer, J. P., Stanley, D. J., Herscovitch, L., \&Topolnytsky, L. (2002). Affective, continuance, and normative commitment to the organization: A meta-analysis of antecedents, correlates, and consequences. Journal of Vocational Behavior, 61(1), 20-52.

Meyer, J. P., Allen, N. J., \& Gellatly, I. R. (1990). Affective and continuance commitment to the organization: evaluation of measures and analysis of concurrent and time-lagged relations. Journal of Applied Psychology, 75, 710-720.

Moore, H. L., \& Moore, T. W. (2014). The effect of ethical climate on the organizational commitment of faculty members. Journal of Academic and Business Ethics, 9(12), 1-15.

Mowday, R. T., Porter, L. W., \& Steers, R. M. (2013). Employee-organization linkages: The psychology of commitment, absenteeism, and turnover. Academic press. 
Nunnally, J. C., \& Bernstein, I. H. (1994). Validity. Psychometric theory, 3, 99-132.

Padmavathy, M \&Premavathy, N. (2018). Influence of demographic variables on organizational commitment. International journal of research in engineering, science and Management, 10 (1), 722-725.

Pala, F., Eker, S., \&Eker, M. (2008). The effects of demographic characteristics on organizational commitment and job satisfaction: An empirical study on Turkish health care staff. The Journal of Industrial Relations \& Human Resources, 10(2), 54-75.

Parveen, N. (2015). Organizational commitment in relation to biographic variations among college teachers. Journal of Research in Social Sciences, 3(1), 96-105.

Pohlman, R., \& Gardiner, G. (2000). Value driven management: How to create and maximize value over time for organizational success. AmacomDiv American MgmtAssn, New York, NY.

Porter, L. W., Crampon, W. J., \& Smith, F. J. (1976). Organizational commitment and managerial turnover: A longitudinal study. Organizational Behavior and Human Performance, 15(1), 87-98.

Porter, L. W., Steers, R. M., Mowday, R. T., \& Boulian, P. V. (1974). Organizational commitment, job satisfaction, and turnover among psychiatric technicians. Journal of Applied Psychology, 59(5), 603-609.

Rhodes, S. R., \& Steers, R. M. (1981). Conventional vs. worker-owned organizations. Human Relations, 34(12), 1013-1035.

Ritzer, G., \& Trice, H. M. (1969). An empirical study of Howard Becker's side-bet theory. Social forces, 475-478.

Robbins, S. P., \& Langton, N. (2003). Organizational behavior: Concepts, controversies, application. Canada: Pearson Education, 3-31.

Rousseau, D. M., \& Parks, J. M. (1993). The contracts of individuals and organizations. LL Cummings, 8.

Sabir, F. S., Maqsood, Z., Tariq, W., \&Devkota, N. (2019). Does happiness at work lead to organisation citizenship behaviour with mediating role of organisation learning capacity? A gender perspective study of educational institutes in Sialkot, Pakistan. International Journal of Work Organisation and Emotion, 10(4), 281-296.

Salami,S.O. (2008). Demographic and psychological factors predicting organizational commitment among industrial workers. Anthropologist, 10, 31-38.

Salancik, G. R. (1977). Commitment and the control of organizational behavior and belief. New directions in organizational behavior, 1, 54 .

Saremi, H., \&Bahdori, S. (2015). The relationship between critical thinking with emotional intelligence and creativity among elementary school principals in Bojnord city, Iran. International Journal of Life Sciences, 9(6), 33-40.

Schmitt, N. (1996). Uses and abuses of coefficient alpha. Psychological Assessment, 8(4), 350-353. doi:10.1037/1040-3590.8.4.350.

Sepahvand, F., Atashzadeh-Shoorideh, F., Parvizy, S., \&Tafreshi, M. Z. (2017). The relationship between some demographic characteristics and organizational commitment of nurses working in the Social Security Hospital of Khorramabad. Electronic physician, 9(6), 4503.

Sezgin, F. (2009). Relationships between teacher organizational commitment, psychological hardiness and some demographic variables in Turkish primary schools. Journal of Educational Administration. http://dx.doi. org/10.1108/09578230910981099.

Sigh, K., \&Sifflette, L. (1996). Teacher's Perspective on Professional Development. Journal of Personal Evaluation, 10, 143-158.

Shaw, J., \& Reyes, P. (1992). School cultures: Organizational value orientation and commitment. The Journal of Educational Research, 85(5), 295-302.

Shrestha, I. (2019a). Influence of demographic factors on job satisfaction of university faculties in Nepal. NCC Journal, 4(1), 59-67.

Shrestha, M. (2019b). Contribution of school related attributes on job satisfaction: A cross- sectional study on school teachers in Nepal. Malaysian Online Journal of Educational Management, 7(4), 23-44.

Steers, R. M., \& Spencer, D. G. (1977). The role of achievement motivation in job design. Journal of Applied Psychology, 62(4), 472. 
Steers, R. M. (1977). Antecedents and outcomes of organizational commitment. Administrative Science Quarterly, 46-56.

Tarter, C.J., Hoy, W.K. and Kottkamp, R.B. (1990). School health and organizational commitment. Journal of Research and Development in Education,23(4), 236-42.

Tett, R. P., \& Meyer, J. P. (1993). Job satisfaction, organizational commitment, turnover intention, and turnover: path analyses based on meta-analytic findings. Personnel psychology, 46(2), 259-293.

Tough,A., \&Popoola, S. O. (2009). Organizational commitment of records management personnel in Nigerian private universities. Records Management Journal, 19(3), 204-217. https://doi.org./10.1108/09565690910999193.

Tsui, K.T. and Cheng, Y.C. (1999). School organizational health and teacher commitment: a contingency study with multi-level analysis. Educational Research and Evaluation, 5(3), 249-68.

Turner, B. A., \&Chelladurai, P. (2005). Organizational and occupational commitment, intention to leave, and perceived performance of intercollegiate coaches. Journal of Sport Management, 19(2), 193-211.

Wagner, J. A., \& Hollenbeck, J. R. (2010). Organizational Behavior: Securing Competitive Advantage. Routledge. New York.

Warr, P. (1987). Work, unemployment, and mental health. Oxford University Press.

Wiener, Y. (1982). Commitment in organizations: A normative view. Academy of Management Review, 7(3), 418428.

Zimkund, W. G. (2003). Business research methods (7thed.). Ohio: Thomson Learning South Western. 